\title{
Historical Analysis of School Choice in Ontario: Freedom of Choice and Inequality
}

\author{
Peter J. Glinos \\ Queen's University
}

\section{Abstract}

The article analyzes the contemporary school choice debate in Ontario in relation to the neoliberal models of education instituted by other provinces, and places key issues of the debate within Canada's historical context. In the first section, this paper focuses on tracing out the push for neoliberal school choice in Ontario within the broader history of its development in Canada, with particular attention to Alberta and British Columbia. The second section examines two aspects of the school choice debate: the issues of freedom of choice, as well as racial and social inequality. Finally, these aspects of school choice are placed alongside Milton Friedman's voucher school model and the history of education in Ontario. This juxtaposition reveals some of the regulations needed to mitigate the harmful effects of school choice in Ontario.

Keywords: school choice, vouchers, neoliberalism, Ontario, Canada, Milton Friedman, Doug Ford

ISSN 2560-8371

DOI: https://doi.org/10.24908/encounters.v22i0.15072

(C) Encounters in Theory and History of Education | 153 


\section{Análisis histórico de la elección de centro escolar en Ontario: libertad de elección y desigualdad}

\section{Resumen}

El propósito de este artículo es analizar el debate contemporáneo sobre la elección de centro escolar en Ontario en relación con los modelos de educación neoliberal adoptados por otras provincias, y ubicar los temas clave del debate dentro del contexto histórico de Canadá. En la primera sección, este documento se centrará en rastrear el impulso neoliberal en lo referente a la elección de centro en Ontario dentro de la historia más amplia de su desarrollo en Canadá, con especial atención a Alberta y Columbia Británica. En la segunda sección de este artículo, se examinarán dos aspectos del debate sobre la elección de centro escolar: las cuestiones de la libertad y la elección, así como la desigualdad racial y social. Estos aspectos de la elección de centro escolar se ubicarán en el contexto del modelo de escuela con cupones de Milton Friedman y la historia de la educación en Ontario. Esta yuxtaposición revelará algunas de las regulaciones necesarias para mitigar los efectos dañinos de la elección de escuelas en Ontario.

Palabras clave: elección de escuela, vales, neoliberalismo, Ontario, Canadá, Milton Friedman, Doug Ford

\section{Analyse historique des choix d'écoles en Ontario; la liberté de choix et l'inégalité}

\section{Résumé}

Cet article vise à analyser le débat au sujet du choix contemporain en Ontario en lien avec les modèles d'éducation néolibérale adoptés par d'autres provinces. L'article veut aussi placer les questions-clés du débat dans le contexte historique du Canada. Dans la première section, l'article essaie surtout de décrire l'effort vers le choix d'une école néolibérale en Ontario, en portant une attention spéciale à l'Alberta et la Colombie Britannique. Dans la deuxième partie, l'auteur examine deux aspects du débat sur les choix scolaires, nommément les questions de liberté et d'inégalité raciale et sociale. Celles-ci seront replacées dans le contexte du modèle scolaire de crédit de Milton Friedman et de l'histoire de l'éducation de L'Ontario. Cette juxtaposition révélera que 
certaines règlementations étaient nécessaires afin de mitiger les effets nocifs de choix scolaires en Ontario.

Mots-clés : choix scolaires, pièces justificatives, le néolibéralisme, l'Ontario, le Canada, Milton Friedman, Doug Ford

\section{Introduction}

One of the most contentious issues in education, school choice, has reared its head in Ontario. The debate is nested within larger conversations about inclusion, freedom, identity, and the common good. The purpose of this article is to analyze the contemporary school choice debate in Ontario in relation to models of neoliberal education adopted by other provinces, and to place key issues of the debate within Canada's historical context. In the first section, this paper will focus on tracing out the push for neoliberal school choice in Ontario within the broader history of its development in Canada, with particular attention to Alberta and British Columbia. In the second section of this article, two aspects of the school choice debate will be examined: the issues of freedom of choice, as well as racial and social inequality. These aspects of school choice will be placed within the context of Milton Friedman's school voucher model and the history of education in Ontario. This juxtaposition will reveal some of the regulations needed to mitigate the harmful effects of school choice in Ontario.

The term school choice carries with it various connotations, hypocrisies, and aspirations. When hearing the word "choice," many educators will reflexively respond with skeptical questions like, "Choice to do what exactly? Choice for whom?" These are merited concerns and will be addressed in the final section of this article. By school choice, this paper is referring to organizational models of education, with particular attention to Milton Friedman's voucher school system. The final section of this paper will touch on the range of options offered by both public and private schooling, yet its central focus will be to juxtapose Friedman's voucher system with the examples drawn from the history of education in Ontario. Ontario Premier Doug Ford's implementation of voucher-like reforms in Ontario provides the immediate impulse for this analytical intervention.

Another key set of terms is the difference between private and independent schools. Although in some cases there is an overlap, this article will use the term private school to describe for-profit or non-profit schools in the private sector that do not receive funds from the government. The term independent schoo/ refers to schools that are publicly financed but privately administered, often via a voucher-like system, like the ones found in British Columbia. Ontario does not have independent schools; it has private schools. 
The recent promotion of school choice has its origins in the neoliberal market-based reform movement in the last part of the $20^{\text {th }}$ century. ${ }^{1}$ Milton Friedman, part of a circle of intellectuals inspired by the works of economist Friedrich Hayek, would help shape and spread neoliberalism, a theory centered around making market reforms that involved the slashing of government expenditures and the replacement of the public sector with private enterprise, or private sector-like institutions. He and his students, such as the notorious Chicago Boys in Pinochet's Chile, spread these ideas around the world. In time, these ideas would spread from their epicenters into Canada, namely Ronald Reagan's America and Margaret Thatcher's Great Britain. These ideas would inspire a new generation of school choice advocates and reformers, particularly in the provinces of Alberta and British Columbia, but also here in Ontario. ${ }^{2}$

\section{Milton Friedman}

Neoliberalism resulted in many financial reforms to education, but what was Milton Friedman's original idea of financing school choice? The answer is the "denationalization" of education through a voucher system, as stated in his work "The Role of Government in Education (Friedman, 1955)."3 Friedman reasoned that when compared to the public education system, "competitive private enterprise is likely to be far more efficient in meeting consumer demands than either nationalized enterprises or enterprises run to serve other purposes." 4 Hence, he argues for the introduction of competition and consumer choice into public education.

It is crucial to note that he was not advocating for the complete privatization of the public education system, in the sense that he still believed government had a role to play in financing them. Friedman was not in favor of simply slashing the budget of public schools, leaving only private schools in their wake. In fact, he concedes that, "one of the many reasons one cannot privatize education is that it is not feasible to identify individuals or families benefited, or the money value of those who have benefited. That is, it has a large 'neighborhood effect."'5 The term neighborhood effect refers to the fact that the benefit of education, "accrues not only to the child or to his parents but to other members of the society; the education of my child contributes to other people's welfare by promoting a stable and democratic society." ${ }^{6}$ In other words,

\footnotetext{
${ }^{1}$ Bosetti, Lynn, and Dianne Gereluk. Understanding School Choice in Canada. (Toronto, Ontario: University of Toronto Press, 2016), 70, 77.

2 For a brief yet comprehensive history of school choice in Canada before and during the 1980's, I highly recommend Lyn Bosetti \& Dianne Gereluk's work Understanding School Choice in Canada, (Toronto, ON: University of Toronto Press, 2016), 71-93.

3 Milton Friedman, "The Role of Government in Education," 1955, 4.

4 lbid., 5.

5 lbid., 2.

${ }^{6}$ lbid., 2.
} 
if you cannot measure who is benefiting from education, and how much they are benefiting, it is impossible to determine who should pay the bill.

Although he thought that these obstacles prevented the complete privatization of education, Friedman still opposed the financial status quo of the education sector. $\mathrm{He}$ believed that the existing system gave the public sector an unfair advantage. For example, he cites the imbalance of funding between private and public schools as a problem, arguing that the financing of public schools by the government gave them the upper hand over competing private schools. ${ }^{7}$

In an effort to mitigate these problems, Friedman proposed a new system of funding education, a middle way between the current system and the complete privatization of education: the voucher system. According to Friedman, "parents who chose to send their children to other schools would be paid a sum equal to the estimated cost of educating a child in a government school, provided that at least this sum was spent on education in an approved school." 8 In other words, parents would be granted a voucher - a coupon representing a certain amount of money funded by taxpayers which they could spend in any school they chose. He modeled this system after the American GI Bill (1944), originally aimed at helping WWII veterans returning to the U.S. acquire a post-secondary education in reward for their service. ${ }^{9}$ Under the bill, veterans had the tuition of their selected post-secondary school paid for by U.S. government, leading to substantial gains in higher education for WWII veterans. ${ }^{10}$ In Friedman's system, the amount of money given to the parents would be equivalent to or less than the operating cost of financing a student in a public school.

The government regulations Friedman provides for his voucher system are scarce. The government is asked only to enforce a set of "minimum standards," in the same sense restaurants have certain minimum standards. ${ }^{11}$ The government was also responsible for making sure that there was "the inclusion of a minimum common content" in each school's curriculum. ${ }^{12}$ Although his paper was first published in the 1950s, Friedman would go on to later popularize the idea of his voucher system in the ten-part PBS series, "Free to Choose."13

\footnotetext{
7 lbid., 5.

8 lbid., 6.

9 Ibid., 8; United States Congress, Act of June 22, 1944, Servicemen's Readjustment Act [G.I. Bill of Rights], National Archives and Records Administration, accessed November 22, 2021, https:// catalog.archives.gov/id/299854.

10 John Bound and Sarah Turner, "Going to War and Going to College: Did World War II and the G.I. Bill Increase Educational Attainment for Returning Veterans?" Journal of Labor Economics 20, no. 4 (2002): pp. 784-815, https://doi.org/10.3386/w7452, 784-785.

11 lbid., 3.

12 lbid., 4.

13 "Milton Friedman Speaks: Putting Learning Back in the Classroom (B1235)." YouTube video, accessed September 10, 2021, https://youtu.be/JurdxfNQ0-Q, [28:29 - 29:05].
} 


\section{School Choice in Canada: Alberta and British Columbia}

For this next section, the focus will shift toward two Canadian provinces that have been most influenced by this neoliberal idea of school choice: Alberta and British Columbia. In Canada, Alberta is the only province with charter schools, and remains one of the most supportive of homeschooling. ${ }^{14}$ Likewise, British Columbia (B.C.) has the highest percentage of students enrolled in independent schools compared to any other Canadian province. ${ }^{15}$ Schools within B.C., like Ontario, have a long history of being academically focused, traditional, and religious. ${ }^{16}$

Understanding B.C.'s education system is critical to comprehending school choice in Ontario, where Premier Doug Ford's government has just instituted a voucher-like system. In the event that Ontario models its growing voucher-like system on another Canadian province, then the likeliest choice would be B.C. based on that province having the most developed voucher-like system in Canada. These systems are voucher-like because, under a true voucher system, physical vouchers are distributed directly to parents. In Ontario, a tax credit is given to parents, and in B.C., a grant is given directly to independent schools. Neither system uses a physical voucher, but both allocate funding based on the educational choices of parents. Therefore, understanding the history of school choice in B.C. is of particular importance because it outlines the potential for school choice in Ontario. Furthermore, the parallel placement of their provincial histories reveals the commonalities between the two provinces.

Perhaps one of the most distinguishing features of the Canadian education system is the role of the federal government, or the lack thereof. Canada does not have a national ministry of education; rather, education is a provincial jurisdiction. The federal government has taken a hands-off approach to education, allowing the nation of Quebec and the other provinces autonomy over their education systems.

\footnotetext{
${ }^{14}$ Only Alberta funds the parents directly after they register their child as a homeschooler, making the province the most supportive of homeschooling. Moreover, other resources are shared with parents besides monetary funds. In addition, Alberta offers "blended programs" where a teacher at the local school board provides "planning, resource selection, instructional delivery, assessment and evaluation of student progress in selected courses." Furthermore, homeschooling is guaranteed by Article 29 of the Canadian Charter of Rights and Freedoms, and it has been growing over the past 20 years; Jason Clemens et al., Measuring Choice and Competition in Canadian Education: An Update on School Choice in Canada (Vancouver, BC: Fraser Institute, 2014). 27-28; Government of Alberta, Funding Manual For School Authorities 2012/2013 (Edmonton, Alberta: Alberta Education School Finance Branch, 2012), https://open.alberta.ca/dataset/8f3b4972-4c47-4009-a090-5b470e68d633/resource/fb440809-92b8434f-a9a0-d3927969f8b0/download/2063184-2012-2013-funding-manual-for-school-authoritiesfinal.pdf.

${ }^{15}$ Statistics Canada, February 11, 2018. https://www150.statcan.gc.ca/n1/daily-quotidien/181102/ t001c-eng.htm\#fn02

${ }^{16}$ Lynn Bosetti \& Dianne Gereluk, Understanding School Choice in Canada (Toronto, ON: University of Toronto Press, 2016), 83.
} 


\section{The School Choice Spectrum}

Before moving further, it must be noted that Alberta and B.C. are not the only provinces that have adopted neoliberal policies regarding school choice. For example, every province besides Ontario and the Atlantic provinces funds some form of private or independent education. ${ }^{17}$ In Canada, school choice exists on a spectrum, ranging from the expansion of programs within the public boards, such as alternative education programs and special needs support, to the existence of charter and voucher-like schools. Also, the line between charter and voucher-like schools can be blurred, like in Quebec. The francophone province operates a relatively different school system than the other anglophone provinces, but like many of the anglophone provinces it still funds its independent schools. Yet, the heavy regulation of independent schools that accompanies Quebec's funding has caused its independent schools to be described as more akin to charter schools. ${ }^{18}$ This raises two interesting questions: At what point is a heavily funded and regulated independent school a charter school? Conversely, at what point is a highly deregulated collection of charter schools a voucher system?

\section{Charters in Alberta}

As mentioned above, Alberta is the only province within Canada that permits charter schools. Charter schools are schools which are granted funding from the government on the condition that they follow an agreed upon mandate, otherwise known as a charter. To clarify any misconceptions, Milton Friedman did not recommend charter schools. As outlined above, he opted for a voucher model to finance education. This disconnect is an example of the discrepancy between the neoliberal discourse of Milton Friedman and the manifestations of neoliberal policy. Nonetheless, Friedman did advocate for the introduction of market forces into the public sector to strengthen performance, spark innovation, and to hold down costs. Because of Alberta's adoption of these principles, out of all the Canadian provinces it is considered to have been "the most responsive to [the neoliberal-inspired] educational reform agenda." 19 Resulting from a "series of right-wing parties elected without interruption for almost 80

\footnotetext{
17 Jason Clemens et al., Measuring Choice and Competition in Canadian Education an Update on School Choice in Canada (Vancouver, BC: Fraser Institute, 2014), ii.

18 Lynn Bosetti \& Dianne Gereluk, Understanding School Choice in Canada (Toronto, ON: University of Toronto Press, 2016), 84; Stephen J. Caldas and Sylvain Bernier, "The Effects of Competition from Private Schooling on French Public School Districts in the Province of Québec," The Journal of Educational Research 105, no. 5 (2012): pp. 353-365, https://doi.org/10.1080/00220671.2011.627400, 354.

${ }^{19}$ Lynn Bosetti \& Dianne Gereluk, Understanding School Choice in Canada (Toronto, ON: University of Toronto Press, 2016), 77.
} 
years," the province approved school choice initiatives, partial funding of accredited private schools, homeschooling supports, and standardized testing. ${ }^{20}$

Stemming from the growth of neoliberal ideas, charters were established in Alberta in 1994 under Premier Ralph Klein. According to the provincial government, a charter school is a "public school that provides a basic education in a different or enhanced way to improve student learning and contributes to educational choice ... and to complement the educational services provided in the local public system." 21 The validity of this claim is called into question when one considers the budget cuts to the public system that accompanied the introduction of this neoliberal reform.

Alberta's implementation of charter schools contrasts with Friedman's desire to have the government directly finance individuals who choose private schools. In the charter school model, parents choose amongst schools-public and independent-whose mission statement is directly approved by the government. In the voucher model, parents choose from amongst a host of independent schools who are only required to pass minimal standards. Because both charter and public schools require the direct approval of their mission statement by the government, the establishment of charters more closely resembles the establishment of public schools than voucher schools. On the other hand, the introduction of charter schools draws upon many of the principles espoused by Friedman, such as the use of competition to fuel innovation. The Alberta government stated that the introduction of charters would allow the "opportunity for successful educational practices to be recognized and adopted by other public schools for the benefit of more Albertans."22 The province established charter schools shortly after a national debate about Canada's ability to compete in the global marketplace. ${ }^{23}$ This debate mined the vein of anxiety that schools were failing to prepare children for the future, setting the stage for charter schools and Friedman-like reforms as a means of addressing these concerns.

Charter schools in Alberta are not without their regulations. They must be non-profit organizations bound by an agreed-upon mandate (or charter) between themselves and the government to follow a certain pedagogical approach. In addition, they are not allowed to charge tuition fees or have a religious affiliation. ${ }^{24}$ All the teachers must be certified, but they are restricted from gaining full membership with the Alberta's

\footnotetext{
20 lbid., 77, 85.

${ }^{21}$ Alberta Education, Charter Schools Handbook (Edmonton, Alberta: Field Services, 2021), https://open.alberta.ca/dataset/77e47b84-d8ff-4f2e-a77e-1db5c893595d/resource/c835df44-1cca4252-8f60-2cf00bd66811/download/edc-charter-schools-handbook-2021-02.pdf, 4.

22 Ibid., 4.

${ }^{23}$ Lynn Bosetti \& Dianne Gereluk, Understanding School Choice in Canada (Toronto, ON: University of Toronto Press, 2016), 86-87.

${ }^{24}$ Alberta Minister of Education. Bill 19 School Amendment Act 1994. Accessed September 12, 2021. https://docs.assembly.ab.ca/LADDAR_files/docs/bills/bill/legislature_23/session_2/19940210_bill019.pdf. Division 2.1.
} 
Teachers Association. ${ }^{25}$ Like many other teachers' unions, the Alberta Teachers' Association sees charter schools as a threat to public schooling. ${ }^{26}$ In terms of financing, charter schools manage their own funding and can receive the same perpupil grants as public schools. ${ }^{27}$ Each school's charter is subject to review by the ministry of education every five years. After 2012, charter schools could apply to have their review every 15 years, as well as raise the limit of their enrolment. ${ }^{28}$

In 2009, a concept paper was released by the Alberta government with the vision of expanding charter schools to help explore new forms of pedagogy and funding practices. ${ }^{29}$ This expansion was carried out in 2020, when Premier Jason Kenny's government announced the opening of Alberta's first new charter school in 13 years, New Humble Centre School. ${ }^{30}$ Shortly beforehand, a 2019 survey was conducted to assess Albertans' disposition towards "education choice." It found that $62 \%$ of respondents selected "somewhat satisfied" or "very satisfied" when asked, "Are you satisfied with the current amount of choice in education in Alberta?" Moreover, 59\% were somewhat/very satisfied with the amount of information available about school choice." 31 This statistic is misleading because only $17 \%$ answered that they were "somewhat/very dissatisfied" with the current amount of choice, and only $10 \%$ were "somewhat/very dissatisfied" with the information available. Nonetheless, despite these figures, the survey was presented by the government as a reason to double down on school choice. As a result, Bill 15, The Choice in Education Act, was passed and came into effect the next year. ${ }^{32}$ This act reaffirmed that Alberta's charter schools were, "valued and integral in providing choice in education to students and parents." 33

\footnotetext{
${ }^{25}$ Charter schools teachers may only gain "associate" as opposed to "active membership." Alberta Teachers' Association. https://www.teachers.ab.ca/About\%20the\%20ATA/Membership/Pages/ default.aspx

26 Michael Mindzak, "What Happened to Charter Schools in Canada?" Equity \& Excellence in Education 48, no. 1 (February 2015): 105-117, https://doi.org/10.1080/10665684.2015.991162.

27 Lynn Bosetti \& Dianne Gereluk, Understanding School Choice in Canada (Toronto, ON: University of Toronto Press, 2016), 87.

28 Ibid., 87-88

29 Charter School Concept Paper, (Government of Alberta, 2009), https://open.alberta.ca/dataset/19acfdd7-f817-406b-a97d-aff203796be1/resource/0c8d2adc-d35f4c01-8960-222c85bca05d/download/edc-charter-school-concept-paper.pdf, 1-4.

30 Janet French, "First New Charter School in 13 Years Could Open in Alberta," CBC News, October 4, 2020, https://www.cbc.ca/news/canada/calgary/charter-school-cap-removal-criticized-1.5164989.

${ }^{31}$ Respondents could select from "very satisfied, somewhat satisfied, neutral, somewhat dissatisfied, very dissatisfied, or don't know" in addition to refusing to answer the question. Survey Highlights (Alberta Education, 2020), https://open.alberta.ca/dataset/9dc29fa3-888f-4942-94ae-3348a544f62a/ resource/63205041-e109-44a4-b12c-ebf3eecabc4d/download/edc-survey-highlights-choice-ineducation-2020-05.pdf, 15-16.

${ }^{32}$ Legislative Assembly of Alberta, Bill 15 Choice in Education Act, 2020, https://docs.assembly.ab.ca/ LADDAR_files/docs/bills/bill/legislature_30/session_2/20200225_bill-015.pdf; Government of Alberta, "Protecting Choice in Education," May 28, 2020, https://www.alberta.ca/release.cfm?xID=71459A 1642543-0985-9A93-C18D61E2A25252C5.

33 Government of Alberta, Bill 15 Choice in Education Act, 2020, 1.
} 
In addition to legislative support, charter schools in Alberta continue to have long wait lists. ${ }^{34}$ This means that charters have reached the critical mass of parental support necessary for their continued existence, potentially setting the stage for their increased growth. The rise of charter schools in Alberta also calls into question how committed everyday Canadians are to public education and the principles of equity and social justice. ${ }^{35}$

\section{Voucher-Like Schools in British Columbia}

Neoliberal models of school choice have had a large impact on the nature of the British Columbia's education system. Whereas Alberta strongly embraced charter schools, B.C. created Canada's most comprehensive voucher-like school model, leading to the financing of a relatively expansive selection of independent schools. In the early years of B.C.'s school choice movement, several voucher-like models were proposed, all varying in their degrees of regulation and caveats. In 1977, the one that was chosen was described as the "unregulated model" of the Friedman Plan. ${ }^{36}$ The main difference between B.C.'s and Friedman's models was that, under the B.C. model, money was given directly to the school in the form of an operating grant, sparing independent schools from having to process physical vouchers. ${ }^{37}$ These reforms were legislated by Bill 33, the Independent Schools Support Act, which laid the groundwork for the province's current voucher-like system. ${ }^{38}$

B.C. primarily funded its schools through money collected via a property tax. ${ }^{39}$ Funds directed to independent schools represented "less than $1 \%$ of the budget for the public school system." 40 This means that funding for the province's independent schools was initially a very small portion of the budget, but the redirection of government funds to independent schools increased greatly over time.

34 "Charter School Hopefuls Face Long Waiting Lists," CBC News, September 5, 2013, https://www.cbc.ca/news/canada/calgary/charter-school-hopefuls-face-long-waiting-lists-1.1360685.

35 In 2015, scholar Michael Mindzak called charter schools a "failed policy" and a "non-issue," citing the continued commitment Canadians had towards equity and public schooling as the reason for their failure: Michael Mindzak, "What Happened to Charter Schools in Canada?" Equity \& Excellence in

Education 48, no. 1 (February 2015): pp. 105-117, https://doi.org/10.1080/10665684.2015.991162, 113114.

36 Daniel J Brown, "Financial Effects of Aid to Nonpublic Schools: The British Columbia Experience," Educational Evaluation and Policy Analysis 4, no. 4 (1982): pp. 443-460, https://doi.org/10.3102/ $01623737004004443,459$.

37 Ibid., 444.

38 B.C. Legislature, Independent Schools Support Act, 1977.

39 Daniel J Brown, "Financial Effects of Aid to Nonpublic Schools: The British Columbia Experience," Educational Evaluation and Policy Analysis 4, no. 4 (1982): pp. 443-460, https://doi.org/ 10.3102/01623737004004443, 446.

40 Ibid., 447. 
These funds did not come without regulations. Independent schools needed to be in operation for five consecutive years prior to their application. When the bill was first implemented, qualifying schools were classified into one of two categories for financial assistance. ${ }^{41}$ The first category was Group 1 schools, which received some funding on the condition it was spent on operating expenses apart from teachers' salaries. ${ }^{42}$ Group 2 schools received a greater amount of funding for operating expenses, including teachers' salaries. ${ }^{43}$ Importantly, under B.C.'s system the value of an independent school per-student operating grant is only a fraction of the per-student operating grant received by public schools. ${ }^{44}$ As long as this is true, independent schools that rely solely on operating grants will always get less money to spend perstudent than competing public schools. An exception is aboriginal schools, which receive a per-student operating grant equivalent to the per-student operating cost of a public school, which remains the case to this day. ${ }^{45}$ Because of this, independent schools in B.C. still rely on charging tuition in addition to the money they receive from operating grants. 46

Another milestone in the development of British Columbia's voucher-like system was in 1996, when the B.C. legislature passed the Independent School Act. ${ }^{47}$ The law, as well as the official Mandate for the School System, stated that the goal of the education system was "to enable all learners to become literate, to develop their individual potential, and to acquire the knowledge, skills and attitudes needed to contribute to a healthy, democratic and pluralistic society and a prosperous and sustainable economy." 48 Under this framework, the act expanded the regulation of independent schools to a four-tiered system. ${ }^{49}$ Today, this system has a series of regulations that determine the funding of independent schools. Group 1 schools are required to be non-profit. Their independent school operating grants are valued at $50 \%$ of the per-student operating costs in the public system. (In 2018-19, it was 50\% of the public system's $\$ 7,423$ per-student operating cost, although this number can increase with children who have special needs.) After Grade 9, student funding is drawn on a

41 Ibid., 447.

${ }^{42}$ At the time, teachers' salaries tended to be the biggest expense.

43 Ibid., 447.

44 Ibid., 447-448.

45 David Hunt and Deani Van Pelt, Who Chooses Independent Schools in British Columbia and Why? (Ottawa: Cardus, 2019), 10-12, accessed September 30, 2021, https://www.cardus.ca/research/ education/reports/who-chooses-independent-schools-in-british-columbia-and-why/

46 Ibid., 17-18.

47 B.C. Legislature, Independent School Act, (Victoria, 1996). https://www.bclaws.gov.bc.ca/civix/ document/id/complete/statreg/96216_01

48 Province of British Columbia, Framework for Enhancing Student Learning, (Hansard Services, January 13, 2021), https://www2.gov.bc.ca/gov/content/education-training/k-12/administration/ legislation-policy/public-schools/framework.

${ }^{49}$ B.C. Legislature, Independent School Act, (Victoria, 1996), Section 4. 
per-course basis: $\$ 215$ for a partial course, and $\$ 430$ for a full credit course in 2019$20 .{ }^{50}$ Additionally, Group 1 schools must hire government certified teachers, cover many parts of the government mandated curriculum, and participate in government assessments. ${ }^{51}$ Distributed learners, those who partake in homeschooling through a supervising authority, also fall under Group $1 .{ }^{52}$ The second category, Group 2 schools, must also be non-profit, but their per-student operating expenses can exceed those of public schools. As a result, they can only receive $35 \%$ of the operating cost funding given to public schools, apart from distance learners, for whom they can receive 44.1\%. Group 3 schools can be for-profit, and often are. These schools do not receive any taxpayer funding because they are only required to meet Section 1 requirements of the Independent Schools Act, the minimum standard. ${ }^{53}$ Nonetheless, half the students enrolled in Group 3 schools must be B.C. residents, with parents who are Canadian citizens or permanent residents. Lastly, Group 4 schools can also be for-profit, and they do not receive taxpayer funding. These schools often enroll many international or interprovincial students and are typically university preparatory schools. ${ }^{54}$ Schools from each of the four groups form various independent schools' associations, with some independent schools joining multiple associations. ${ }^{55}$

The general trend in B.C. is that the more regulations an independent school follows, the more funding it can obtain from the government. Despite these regulations, independent schools can still charge tuition, residence, and extra fees. ${ }^{56}$ This is in line with Milton Friedman's original voucher plan, which did not restrict voucher schools

50 David Hunt and Deani Van Pelt, Who Chooses Independent Schools in British Columbia and Why? (Ottawa: Cardus, 2019), 12, accessed September 30, 2021, https://www.cardus.ca/research/ education/reports/who-chooses-independent-schools-in-british-columbia-and-why/

51 lbid., 10-12.

52 Ibid., 10-12.

53 Section 1 outlaws the existence of schools that would, "in theory or in practice promote or foster doctrines of racial or ethnic superiority or persecution, religious intolerance or persecution, social change through violent action, or sedition" B.C. Legislature (Victoria, 1996), Section 1, a.

${ }^{54}$ Ibid., 10-12. Alberta's total funding provided by Alberta Education for accredited independent schools is 60\%-70\%, higher than B.C.'s 35\%-50\%. Jason Clemens et al., Measuring Choice and Competition in Canadian Education an Update on School Choice in Canada (Vancouver, BC: Fraser Institute, 2014), 25-26.

55 "Of B.C.'s 367 independent schools, 297 are members of the Federation of Independent School Associations British Columbia (FISABC). 3 All FISABC schools are members of at least one of six other associations, with some schools affiliated with multiple associations. All 29 FISABC elite schools belong to the Independent Schools Association of British Columbia (ISABC); 134 independent schools are specialty or religious schools with the Associate Member Group (AMG); 27 are religious schools with the Association of Christian Schools International (ACSIBC); 76 are religious schools with Catholic Independent Schools of British Columbia (CISBC); 14 are religious schools with Seventh Day Adventist British Columbia (SDABC); and 37 are religious schools with the Society of Christian Schools in British Columbia (SCSBC)." David Hunt and Deani Van Pelt, Who Chooses Independent Schools in British Columbia and Why? (Ottawa: Cardus, 2019), 12.

56 David Hunt and Deani Van Pelt, Who Chooses Independent Schools in British Columbia and Why? (Ottawa: Cardus, 2019), 17-18. 
from accepting additional payments. Consequently, families of lower socio-economic background may not be able to access schools that charge high tuition, a point that will be addressed later.

Presently, B.C. continues to operate this growing voucher-like system. At around $13 \%$, B.C. has the highest number of independent schools, nearly double the national average..$^{57}$ This is part of a longstanding trend, with enrollment increasing since $1977 .{ }^{58}$ Additionally, long waitlists are common, comprising around $14 \%$ of some school's total student populations, especially in the Lower Mainland. ${ }^{59}$ Despite the funding directed toward private schools, the vast majority of B.C. students, $86.7 \%$, like the rest of their Canadian counterparts, attend public schools. ${ }^{60}$

\section{History of the Neoliberal School Choice Debate in Ontario}

With the rise of neoliberalism in the 1980s, Conservative Ontario Premier Bill Davis (1971-1985) initiated the reform that sparked the emergence of a public debate over school choice. In 1984, he introduced a bill that extended the funding of Catholic schools from Grade 10 to Grades 11, 12, and 13.61 The subsidy raised questions about whether other independent schools should also be funded. The Shapiro Commission (1985) was appointed to investigate the matter, as well as the regulations that should accompany such a reform. The commission issued a report advocating for the financing of independent schools, stating:

That, as a matter of public policy, and so long as the public policy objectives [of public schooling] are not substantially eroded, new initiatives both in the public support of private schools and in the relationship of these schools to the public schools should be actively developed and tested. 62

Although the commission's recommendations were not passed into legislation under Bill Davis, they can be understood as a major step in the development of school choice in Ontario.

\footnotetext{
57 Statistics Canada, February 11, 2018. https://www150.statcan.gc.ca/n1/daily-quotidien/181102/ t001c-eng.htm\#fn02.

58 David Hunt and Deani Van Pelt, Who Chooses Independent Schools in British Columbia and Why? (Ottawa: Cardus, 2019), 8.

59 Clemens, Jason. Wait Lists for Independent Schools in British Columbia's Lower Mainland. Policy File. The Fraser Institute, 2012. 8.

60 Statistics Canada, February 11, 2018. https://www150.statcan.gc.ca/n1/daily-quotidien/181102/ t001c-eng.htm\#fn02

${ }^{61}$ Steve Paikin, July 4, 1985; Derek J. Allison, Bringing School Choice to Ontario, (Vancouver, B.C.: Fraser Institute, 2020), https://www.fraserinstitute.org/studies/bringing-school-choice-to-ontario, ii, 21.

62 Bernard J. Shapiro, The Report of The Commission on Private Schools in Ontario (Toronto, ON: Ministry of Education, 1985), pp. 1-265, https://archive.org/details/reportofprivschools00comm, 40.
} 
The late 1990's witnessed the rise of Premier Mike Harris (1995-2002). He too, like Davis, initiated a debate over school choice. His conservative reforms under Bill 160 led to an infamous two-week walk-out by teachers in October of $1997 .{ }^{63}$ Continuing down the warpath, on August 30th, 2001, Harris's Finance Minister, Jim Flaherty, introduced the Equity in Education Tax Credit (EETC), "intended to support parents who [were seeking] more choice in education for their children." 64 The bill went on to say that although "some parents choose to send their children to an independent school, for many the cost is prohibitive. The Government believes it is time to address the needs of these parents." 65 The EETC made it possible for families to send their child to a private school, and then collect a sum of money to recover part of their school's tuition expense at the end of the year. The system was to be financed by the government and is reminiscent of Milton Friedman's voucher plan. Immediately, the opposition New Democratic and Liberal parties opposed the program within the legislature, but it passed nonetheless. ${ }^{66}$

In the Ontario provincial election of 2003, Liberal party candidate Dalton McGuinty (2003-2013) defeated the Conservatives and rose to power as Premier of Ontario. Education was a major issue in the 2003 provincial election and the liberals won -in part-because of their opposition to the educational reforms of Mike Harris. The victory was achieved in spite of support for private schools peaking at 34\% in 2002, the highest level of support they have ever had. ${ }^{67}$ The newly elected Liberals quickly repealed the EETC within its first year, preventing parents from taking advantage of the tax credit. In essence, this retroactively revoked the ETCC, nullifying any claims to recover tuition expenses.

In the 2007 election campaign, education emerged as a wedge issue between the Progressive Conservative and Liberal parties once again. Conservative candidate John Tory had a plan to appoint (former Premier) Bill Davis to help create even more government-funded, faith-based school boards in addition to Catholic schools. ${ }^{68}$ Tory lost the election to Dalton McGuinty, in large part because of his adherence to his

63 "Why Ontario Teachers Went on a Province-Wide Strike in 1997." CBC News. (CBC/Radio Canada, February 21, 2020), https://www.cbc.ca/archives/why-ontario-teachers-went-on-a-province-wide-strikein-1997-1.5466962.

64 Ontario Ministry of Finance (Toronto, August 30, 2001), 1.

65 Ibid., 1.

66 "Suck It and See; Education in Canada; School Vouchers in Ontario," The Economist 359, no. 8228 (June 30, 2001), 1.

${ }^{67}$ Doug Hart and Arlo Kempf, Public Attitudes Towards Education in Ontario 2018, vol. 20 (Toronto, ON: Ontario Institute for Studies in Education of the University of Toronto, 2018), pp. 1-68, https://www.oise.utoronto.ca/oise/UserFiles/Media/Media_Relations/OISE-Public-Attitudes-Report2018_final.pdf, table 2.3, p. 65.

68 Gillespie, Kerry. "John Tory Puts Faith in School Religion.” Toronto Star, July 24, 2007. https://www.thestar.com/news/ontario/2007/07/24/john_tory_puts_faith_in_school_religion.html. 
stance on education. ${ }^{69}$ Tory was also defeated by Liberal incumbent Kathleen Wynne in his own riding of Don Valley West, a fierce opponent of his educational policy. After his defeat, "there was apparently no discussion about how Mr. Tory would obtain a seat in the legislature, which would presumably require a Conservative member to resign."70 Interestingly enough, Kathleen Wynne succeeded Dalton McGuinty as Premier of Ontario in 2013, holding the position until she was defeated in 2018 by the current Conservative Party Premier Doug Ford. ${ }^{71}$

Since coming into office, Doug Ford's administration has taken on the conservative mantle of advocating for school choice. Before the release of his budget for 2021, the former Education Minister, Lisa Thompson, was accused by the Canadian Centre for Policy Alternatives (CCPA) of trying to implement a system of "vouchers by stealth" for children with special needs. ${ }^{72}$ Moreover, in 2019, Doug Ford increased the total education budget, but disproportionately less so when compared to the student population increase. This meant that the total budget was increased, yet the perstudent operating budget was lowered. ${ }^{73}$ Ahead of the 2021 budget's release, there was a considerable buzz around Doug Ford initiating another school choice polemic after the COVID-19 pandemic. ${ }^{74}$ Some feared that the pandemic paved the way for vouchers with the rise of "learning pods," parents pooling resources to take their

69 Howlett Karen, "Tory Admits Faith-Based Schools Funding Mistake." The Globe and Mail, October 25, 2007, https://www.theglobeandmail.com/news/national/tory-admits-faith-based-schools-fundingmistake/article18147998/.

70 lbid.

71 Ferguson, Rob. "Doug Ford Wins Riding as Progressive Conservatives Sweep to Power." Toronto Star, June 7, 2018. https://www.thestar.com/news/queenspark/2018/06/07/doug-ford-wins-riding-asprogressive-conservatives-sweep-to-power.html.

72 Shaker, Erika. "Frontlines of the Class." The Monitor, March 1, 2019. https://www.policy alternatives.ca/publications/monitor/frontlines-class.

73 In 2019 "The province announced the 2019-2020 school board funding on Friday, and it shows that boards will get $\$ 12,246$ per-pupil, versus the $\$ 12,300$ they got in this school year. [...] Rise in the cost of per-pupil funding to $\$ 12,525$ in 2020-21, $\$ 250$ more than the previous year to help deal with COVID-19"; "Ontario Boosts Per Pupil Funding Amount by Two Per Cent, Spending $\$ 736$ Million More in Public Education." The Review, June 19, 2020. https://thereview.ca/2020/06/19/ontario-boosts-per-pupilfunding-amount-by-two-per-cent-spending-736-million-more-in-public-education/; "Ontario Slightly Increases School Board Funding, but per-Student Amount Drops Social Sharing." CBC News, April 26, 2019, https://www.cbc.ca/news/canada/toronto/ontario-marginally-increases-school-board-funding1.5112315.

74 Jason Kunin, "Pandemic Has Cleared the Way for Doug Ford's Plans to Privatize Education." Rabble, September 22, 2020, https://rabble.ca/news/2020/09/pandemic-has-cleared-way-doug-fordsplans-privatize-education; Tom Shea, "The Problem with Voucher Education." The Hamilton Spectator, February 29, 2020, https://www.thespec.com/opinion/columnists/2013/01/28/the-problem-withvoucher-education.html; Matthew Lau, "After Doug Ford, Maybe Ontario's Liberals Will Finally Embrace School Choice." Financial Post, February 6, 2019, https://financialpost.com/opinion/matthew-lau-afterdoug-ford-maybe-ontarios-liberals-will-finally-embrace-school-choice; The Agenda with Steve Paikin. School Vouchers Anyone? TVO, Nov. 22, 2018. https://www.youtube.com/watch?v=a8TZIhpIV6c\&ab_ channel=TheAgendawithStevePaikin. 
students out of the public system and teach them independently. ${ }^{75}$ On March 24, 2021, these concerns were validated when Ford's Progressive Conservatives passed the budget, introducing a voucher-like tax credit along with cuts to public education. ${ }^{76}$ This was done with the rhetoric of helping Ontarians recover from the pandemic. ${ }^{77}$

\section{Present Day Ontario}

Let us now turn to what is happening on the ground here in Ontario. As mentioned earlier, unlike B.C., Alberta, Saskatchewan, Quebec, and Manitoba, only Ontario and the Atlantic provinces avoid funding private or independent schools. ${ }^{78}$ Yet, this does not mean that Ontario's parents are strong supporters of public schooling. Since the 1980s, approval rates for public schools in Ontario have been hovering around 50\%. ${ }^{79}$ Furthermore, in 2014 and 2016, Ontario had a higher percentage of students enrolled in private schools than Alberta. ${ }^{80}$ This growing demographic might create a base of support for school choice reforms, like charters and vouchers. Private schooling in Ontario has increased both in absolute numbers and as a percentage of the students in the education system. ${ }^{81}$ Furthermore, nearly half of these schools have a religious affiliation, ${ }^{82}$ and about one third offer special pedagogical approaches, such as

\footnotetext{
75 In the U.S., Davos exploited COVID-19 relief money to incentivize the creation of voucher school programs. Morgan Sharp, "Scarcity Is the Point, Says Critic of Ford's Back-to-School Fail," Canada's National Observer, October 15, 2020, https://www.nationalobserver.com/2020/10/15/news/scarcitypoint-says-critic-fords-back-school-fail; Erica L. Green, "DeVos Funnels Coronavirus Relief Funds to Favored Private and Religious Schools," The New York Times, May 15, 2020, https://www.nytimes.com/ 2020/05/15/us/politics/betsy-devos-coronavirus-religious-schools.html.

76 "Ontario Child Care Tax Credit," Government of Ontario, accessed November 14, 2021, https://www.ontario.ca/page/ontario-child-care-tax-credit.

77 Ontario Finance Minister Peter Bethlenfalvy, 2021 Ontario Budget Speech, 2021, 61-66.

78 "Provincial Funding for Private Schools," Our Kids, accessed September 13, 2021, https://www. ourkids.net/school/provincial-funding-for-private-schools.

79 Doug Hart and Arlo Kempf, "Public Attitudes Towards Education in Ontario 2018," vol. 20 (Toronto, ON: Ontario Institute for Studies in Education of the University of Toronto, 2018), pp. 1-68, https://www. oise.utoronto.ca/oise/UserFiles/Media/Media_Relations/OISE-Public-Attitudes-Report-2018_final.pdf, 10.

80 Although Alberta has a higher percentage of homeschoolers (1.6\%) than Ontario (0.2\%), these statistics counter the paradigm that parents in Ontario are more committed to their public schools than the Western provinces. Jason Clemens et al., Measuring Choice and Competition in Canadian Education an Update on School Choice in Canada (Vancouver, BC: Fraser Institute, 2014), 26-27; Lynn Bosetti \& Dianne Gereluk, Understanding School Choice in Canada (Toronto, ON: University of Toronto Press, 2016), 85.

81 Ontario Ministry of Education, 2019.

82 Deani Van Pelt, David Hunt, and Johanna Wolfert, Who Choses Ontario Independent Schools and Why? (Ottawa: Cardus, 2019), https://www.cardus.ca/research/education/reports/who-chooses-ontarioindependent-schools-and-why/, 7-8.
} 
Waldorf, Montessori, special education, distance learning, etc. ${ }^{83}$ Perhaps the most interesting pattern of all is that most parents who are turning to private schools went to public schools for the entirety of their own education. ${ }^{84}$ This suggests a demographic shift from public to private in Ontario.

\section{Aspects of School Choice: Freedom of Choice and Inequality}

One of the central arguments presented by Friedman in support of neoliberal education reforms is that "the denationalization of education would widen the range of choice available to parents." 85 Moreover, he argues "the interjection of competition would do much to promote a healthy variety of schools." 86 Therefore, Friedman's argument for school choice hinges on whether his reforms can deliver on their promises of increasing "freedom of choice."

To safeguard this freedom of choice, both Friedman and one of the leading proponents of school choice in Ontario are in favor of regulations that uphold a minimum standard, but they are wary of regulations rendering independent schools indistinguishable from one another. Remember, Friedman himself advocated for "certain minimum standards" and "the inclusion of a minimum common content." 87 In his work, "Bringing School Choice to Ontario," Dr. Derek Allison accepts that "independent schools receiving public monies would be required to comply with appropriate regulations and accept suitable supervision." 88 That being said, he dismisses the idea of "having non-public schools comply with the same criteria as public schools" because it would "nonetheless defeat the object of any school-choice policy." 89 After all, if schools cannot be allowed to differentiate themselves, can one really create different schools to choose from?

But what are the existing regulations for private schools within Ontario? Private schools in Ontario are subject to ministry inspections. They must pay fees for these inspections if they wish to offer credit courses, in addition to per-pupil fees required for

\footnotetext{
83 Derek J. Allison, Sazid Hasan, and Deani Van Pelt, "A Diverse Landscape: Independent Schools in Canada," June 2016, https://www.fraserinstitute.org/sites/default/files/a-diverse-landscapeindependent-schools-in-canada.pdf, iii-v.

84 Deani Van Pelt, David Hunt, and Johanna Wolfert, Who Choses Ontario Independent Schools and Why? (Ottawa: Cardus, 2019), https://www.cardus.ca/research/education/reports/who-chooses-ontarioindependent-schools-and-why/, 9-10.

85 Milton Friedman, "The Role of Government in Education," 1955, 5.

86 Ibid., 6.

87 Ibid., 4.

88 Derek J. Allison, "Bringing School Choice to Ontario," Fraser Institute, September 8, 2020, https://www.fraserinstitute.org/studies/bringing-school-choice-to-ontario, 13.

89 lbid., 13.
} 
participation in provincial tests. ${ }^{90}$ These regulations are far more lax compared to the independent schools of other provinces that receive government funding. ${ }^{91}$ This lack of regulation allows for rise of "credit mills," private schools that deliver high marks in exchange for increased profit margins. This problem was pointed out by the Ontario Auditor General in her 2013 Annual Report, which noted the sharp contrast between the standardized test scores of public and private schools. ${ }^{92}$ Of late, the existence of credit mills is reported to be an ongoing issue. ${ }^{93}$ This suggests that children pay a cost in terms of the quality of their education when there is a lack of regulations to accompany an increase in school choice. Perhaps the greatest argument against school choice is that families have the potential of making the wrong choice when offered good and bad options for their child's education. How can one simply brush this off as the "price of freedom" when children's futures are at stake?

Another argument against school choice in Ontario is the diversity of choices already found within the public system. Historically, the dual-colonization of Canada, first by French Catholics and then by British Protestants, left Ontario with separate Catholic and Protestant school systems. Today, Ontario has four separate publicly funded school systems: English Public, English Catholic, French Public, and French Catholic. ${ }^{94}$ Generally speaking, Catholic schools allow students from non-Catholic backgrounds to enroll, creating more school choice options in Ontario. Regarding French Immersion schools, there has been a steady increase in enrollment over the past two decades. ${ }^{95}$ In addition, Ontario's public system also offers a wide selection of heritage-language programs geared towards helping families keep their mother tongues. ${ }^{96}$

Besides language-centered schools, there are also several alternative schools and specialty programs offered in the public system. According to the Ontario Ministry of Education, alternative schools exist "to provide an option for some students who have educational needs that cannot be met in their existing schools, and/or to respond to needs expressed in the community." 97 This includes schools that specialize in "the arts, business studies, the environment, languages, pure and applied sciences, or

90 Ontario Ministry of Education, "Private Elementary and Secondary Schools," (Government of Ontario, April 1, 2021), http://www.edu.gov.on.ca/eng/general/elemsec/privsch/.

91 Lynn Bosetti \& Dianne Gereluk, Understanding School Choice in Canada (Toronto, ON: University of Toronto Press, 2016), 85.

92 Office of the Auditor General of Ontario. 2013 Annual Report. (Queen's Printer for Ontario, 2013), https://www.auditor.on.ca/en/content/annualreports/arreports/en13/2013ar_en_web.pdf, 181-183.

${ }^{93}$ Armelia Eaton, "From Grade Inflation to Grade Deflation," The Varsity, September 23, 2018, https://thevarsity.ca/2018/09/23/from-grade-inflation-to-grade-deflation/.

94 Ontario still has a Separate Protestant School Board in Penetanguishene, Ontario. "Welcome to Protestant Separate School Board of the Town of Penetanguishene," https://www.pssbp.ca/.

95 Derek J. Allison, "Bringing School Choice to Ontario," Fraser Institute, September 8, 2020 , https://www.fraserinstitute.org/studies/bringing-school-choice-to-ontario, 5-6.

96 "About ILP," ILEA Ontario, November 15, 2015, https://ilea.ca/news-2/ilp/.

97 Ontario Ministry of Education, 2016, 80. 
technological education." 98 One example of the specialized programs offered within public schooling is the International Baccalaureate (IB) program, a rigorous academic program with branches around the world. ${ }^{99}$ In terms of unique pedagogical approaches, the Thames Valley District School Boards stands out with its "School Within a School" program, a self-directed learning program that allows students to pursue their own research interests (within the boundaries of the provincial curriculum). 100

Additionally, there is a diverse range of alternative schools and programs nested within the Toronto District School Board (TDSB). Famous for its adoption of alternative private schools born out of the 1960s, the board hosts a wide array of schools with unique approaches such as City School, ALPHA, and Contact Alternative School. ${ }^{101}$ In 2009, the TDSB passed "the mandate" for DaVinci School, a Waldorf-inspired school. ${ }^{102}$ In the same year, they created the Afri-centric Alternative School "in response to an initial community request for such a school in June 2007 to address a high dropout rate and achievement gap affecting students of African descent."103 These schools are reminiscent of Alberta's charter schools because of their specialized mission statements, creation at the behest of the local communities, and the sanctioning of their establishment by the local schoolboard.

Despite this diversity within Ontario's public system, proponents of school choice in Ontario still claim that there would be more options with the implementation of neoliberal reforms. ${ }^{104}$ In the Free to Choose series, Friedman argues that, insomuch as the options for school are under the control of a school board, the range of choices

\footnotetext{
98 lbid., 80.

99 International Baccalaureate Schools of Ontario, IB Programme of Ontario Schools. (Toronto: 2008), https://www.tcdsb.org/schools/michaelpowerstjoseph/ib/Resources/Documents/IBSO_ Brochure.pdf, 3-9.

100 "School within a School," Thames Valley District School Board, accessed September 14, 2021, https://www.tvdsb.ca/en/programs/school-within-a-school.aspx.

${ }^{101}$ Nina Bascia, Sokolov Esther Fine, and Malcolm Levin, "Alternative Schooling and Student Engagement," 2017, https://doi.org/10.1007/978-3-319-54259-1, 75-86; Myra Novogrodsky, "Looking Backward and Forward: Fifty Years of Alternative Schools," 2017, pp. 95-106, https://doi.org/10.1007/978-3-319-54259-1_7.

102 “Da Vinci School (GR. JK-06)," Toronto District School Board, accessed September 13, 2021, https://www.tdsb.on.ca/Find-your/Schools/schno/5905.

103 "Africentric Alternative School (GR. JK-08)," Toronto District School Board, accessed September 14, 2021, https://www.tdsb.on.ca/Find-your/Schools/schno/3949.

104 Matthew Lau, "Let's Have Diversity of School Choice," Financial Post, June 16, 2020, https://financialpost.com/opinion/lets-have-diversity-of-school-choices; Yvan Guillemette, "Breaking Down Monopolies: Expanding Choice and Competition in Education," C.D. Howe Institute, 2007, https://ofis.ca/wp-content/uploads/2012/08/CD-Howe-Institute-Breaking_Down_Monopolies-October2007.pdf, 4-5; Milagros Palacios and Mark Milke, "Ontario Parents Deserve More School Choices for Their Children," Fraser Institute, December 23, 2015, https://www.fraserinstitute.org/article/ontarioparents-deserve-more-school-choices-their-children; Derek J. Allison, "Ontario Must Reform Educationfor the Benefit of Parents and Students," Fraser Institute, September 7, 2021, https://www. fraserinstitute.org/article/ontario-must-reform-education-for-the-benefit-of-parents-and-students.
} 
can only be as expansive as the board can imagine or allow them to be. ${ }^{105}$ As diverse as the options listed above may seem, they could have been greater if they were generated and chosen by the citizenry as opposed to a committee. The argument is predicated on the idea that the citizens can imagine a wider range of options than a committee. In the voucher plan, citizens are granted the freedom to construct and operate their own visions for what schools could be, provided they garner enough support from parents willing to finance them with their vouchers. To Friedman, the diversity and innovation that emerged from these schools would allow us to surpass the decay and stagnation of the public sector, thereby providing genuine school choice. Despite all of this "choice" within the public system, one of the leading Canadian school choice advocates is quick to point out that the number of independent schools and the percentage of students they enroll has continued to surge for the past two decades. Coupled with the increased growth in French Immersion programs, they argue that parents in Ontario are searching for more alternatives within and outside of the existing public system. ${ }^{106}$

In some ways, one could argue that Ontario already has a voucher-like program, but it is restricted to post-secondary education. Just like the U.S. GI Bill that Friedman was so fond of, the Ontario Student Assistance Program (OSAP) utilizes a voucher-like system of grants for students to pay for college or university. ${ }^{107}$ The program does not instruct students which university to attend, but rather finances their choice of accredited post-secondary programs. Should not proponents of OSAP also support grants for post-secondary students in Ontario? And should opponents of vouchers not also be against funding OSAP? Or, is there a difference between tertiary and secondary schooling that justifies this divide?

As mentioned earlier, for better or for worse, vouchers open the doors to a wider diversity of options for families to choose from. But will families really be able to navigate their way around all these choices, knowing what is best for their children? Genuine choice necessitates the need for easily accessible information. After all, can it really be called "choice" if it is uninformed? Poor and immigrant families may not be able to navigate information as well as wealthy and established families. ${ }^{108}$ To mitigate

105 "Milton Friedman Speaks: Putting Learning Back in the Classroom (B1235)." September 10, 2021, https://youtu.be/JurdxfNQ0-Q, [30:00 - 40:00].

106 Derek J. Allison, "Bringing School Choice to Ontario," Fraser Institute, September 8, 2020, https://www.fraserinstitute.org/studies/bringing-school-choice-to-ontario, 5-6.

107 "Learn About OSAP," Ontario.ca, accessed September 14, 2021, https://www.ontario.ca/page/ learn-about-osap.

108 The Edmonton Public School Board's "Find a School" resource may serve as a model for what might be introduced to Ontario to bring transparency towards choosing a school. The toolkit includes a map of schools, demographic information, costs, test results, and open house events for prospective schools.

"Find a School (2021-22)," Find a School Tool - Edmonton Public Schools, accessed September 16, 2021, https://www.epsb.ca/schools/findaschool/fast/. 
these problems, the OECD emphasizes the importance of making information easily accessible to the public, with particular attention paid to marginalized groups. ${ }^{109}$

Yet, even if families were given all the information they needed, there is the lingering question raised by researchers Bosetti and Gereluk: should "market mechanisms rather than political debate determine the goals and values of education?" 110 Furthermore, what about the creation of socio-economic inequality and its limitations on choice? The threat of school choice to democracy and social cohesion, as well as the capacity for school choice to generate inequality, are key issues and have been deservingly given their own sections.

\section{Economic Inequality}

Critics of school choice argue that it creates a two-tiered system where children from disadvantaged families are left behind, shackled to inferior schools by their geography and lower socio-economic status. In addition to accepting money from vouchers, schools may still charge additional tuition, leaving behind those who cannot afford the costs. As a result, the gap between the rich and the poor widens over time. ${ }^{111}$ Moreover, some independent schools funded by the voucher system might discriminate against people from marginalized groups, barring them from enrolling in their school and exacerbating existing inequalities.

Furthermore, even if vouchers were introduced, not all groups would take equal advantage of them, widening the disparity between groups. An early report on the B.C. system noted the potential of the system to increase inequalities. ${ }^{112}$ When it was first implemented, large schools were more likely to take advantage of the government aid, and groups like the Seventh Day Adventists appeared "unwilling to accept government help." 113 Because these forces work to widen the disparity between groups, opponents to neoliberal reform object to both the charter and voucher models.

\footnotetext{
109 Andreas Schleicher, "School Choice and School Vouchers: An OECD Perspective," www.oecd.org, 2017, https://www.oecd.org/education/School-choice-and-school-vouchers-an-OECD-perspective.pdf, 15.

110 Bosetti, Lynn, and Dianne Gereluk. Understanding School Choice in Canada. (Toronto, Ontario: University of Toronto Press, 2016), 88.

111 Buly A. Cardak, "Education Vouchers, Growth and Income Inequality," SSRN Electronic Journal, 2003, pp. 98-121, https://doi.org/10.2139/ssrn.378660, 98-100.

112 Daniel J Brown, "Financial Effects of Aid to Nonpublic Schools: The British Columbia Experience," Educational Evaluation and Policy Analysis 4, no. 4 (1982): pp. 459.

113 Ibid., 452. This refusal to accept government aid is echoed by a statement issued by the Coalition of Independent Homeschoolers, who claimed that they were not "interested in the approval or endorsement of government agencies or educational organizations" going on to say they were "skeptical about accepting funds or aid from these sources and even about making use of the services they may be interested in offering us." Quoted from Lynn Bosetti \& Dianne Gereluk, Understanding School Choice in Canada (Toronto, ON: University of Toronto Press, 2016), 81.
} 


\section{Exclusionary Practices in School Choice}

Before moving on, this paper will address some of the exclusionary practices existing in contemporary models of school choice in Canada, as well as here in Ontario. Although some charters in Alberta are geared towards helping marginalized groupssuch as the Boyle Street Education Centre for at-risk youth, Almadina Language Charter Academy for English language learners, and Mother Earth's Children's Charter School for Indigenous children ${ }^{114}$ - charters can still deny students from enrolling into their school (unlike public schools). David Johnson's 2013 study identified Alberta's best schools and controlled for student background and socio-economic status. In his analysis, Johnson found charters ranked well above public schools, but he reasoned that this was because these schools could deny entry to weaker applicants, hire better teachers, and screen for interested families via their mandate. ${ }^{115}$

In British Columbia and Ontario, we also see the socioeconomic divide between the families of students enrolled in public as opposed to independent schools. It is key to note that independent schools in B.C. can charge additional tuition, which is a critical difference in comparison to other voucher school models like the one in Sweden. ${ }^{116}$ This practice bars families who are unable to afford the cost of tuition from entering schools that are subsidized by public funds. In the current system in Ontario, wealthy parents can already take their children out of public schools. In his Free to Choose series, Friedman points out the same phenomena in the USA. ${ }^{117}$ The contrast between public schools, Ontario's private schools, and B.C.'s tuition-charging independent schools is evident when one looks at the survey data. Just like independent school parents in B.C., private school parents in Ontario earn more, have higher educations, and are less likely to work blue-collar jobs or run single-parent households. ${ }^{118}$ Curiously, in B.C. the most common occupations for independent school parents are education workers, specifically secondary or elementary school teachers and

\footnotetext{
114 Lynn Bosetti \& Dianne Gereluk, Understanding School Choice in Canada (Toronto, ON: University of Toronto Press, 2016), 89.

115 David Johnson, Identifying Alberta's Best Schools (Toronto, ON: C.D. Howe Institute, 2013), https://www.cdhowe.org/sites/default/files/attachments/research_papers/mixed/e-brief_164_0.pdf, 9.

116 In the Swedish voucher system, where schools are not allowed to select students and tuition fees have a strict limit, there are signs of increased benefit from vouchers. Originally, the funding formula for Sweden's voucher school system was $85 \%$ of public's per-student funding, but it was raised to $100 \%$ in 1997. A study linked competition with increased public-school quality, test scores, and final grades for students in public schools Teacher's salaries also rose because more employers sought them. F.Mikael Sandström and Fredrik Bergström, "School Vouchers in Practice: Competition Will Not Hurt You," Journal of Public Economics 89, no. 2-3 (2005): pp. 351-380, https://doi.org/10.1016/j.jpubeco. 2004.03.004, 353, 356-357, 379.

117 "Milton Friedman Speaks: Putting Learning Back in the Classroom (B1235)." YouTube video, September 10, 2021, https://youtu.be/JurdxfNQ0-Q, [29:19 - 30:38].

118 David Hunt and Deani Van Pelt, "Who Choses Independent Schools in British Columbia and Why?," (Ottawa: Cardus, 2019), 9, 11-17, 20, https://www.cardus.ca/research/education/reports/whochooses-independent-schools-in-british-columbia-and-why/.
} 
educational counsellors. ${ }^{119}$ In Ontario, private school parents are also more than twice as likely to be teachers than those in public schools. ${ }^{120}$

\section{Racial Inequality}

In addition to these economic inequalities, there is a racial divide in Ontario's schools. In 2020, the provincial government launched a commission to investigate anti-black racism within the Peel District School Board, the second largest school board in Canada. Afterwards they released a report asserting an alarming presence of systemic racism within the board. The report highlighted the disproportionately high number of police interventions, disciplinary measures, and lack of administrative representation faced by black students in comparison to other racialized groups. ${ }^{121}$ In addition, there is a deep divide between the indigenous and non-indigenous populations nationwide. In late May 2021, the remains of 215 children were found buried at a former residential school for Indigenous in Kamloops B.C. This tragic discovery served as a reminder of the suffering faced by Indigenous communities and their struggles with the residential school system, in B.C. and Ontario, for both life and identity. This history has contributed to the lower attendance, enrollment, and graduation of Indigenous students in Canada. ${ }^{122}$ Therefore, there is a concern that Friedman's voucher system could widen racial inequalities already present in Ontario, especially if these schools denied the entry of these students.

\section{Friedman on Racial Integration}

In his paper, Friedman mentions how southern U.S. states were considering the use of a voucher-like system of school grants to circumnavigate the Supreme Court's ruling against segregation. ${ }^{123}$ Because private institutions had the right to deny service to customers, publicly financed private schools would have been able to deny black children entry into their schools. At first dissuaded by hearing this, Friedman reconsidered his position. In the end, he chose to hold firm to his belief that voucher

\footnotetext{
119 Ibid., 17.

120 Ibid., 11.

${ }^{121}$ Ena Chandha, Suzanne Herbert, and Shawn Richard, "Review of the Peel District School Board," February 28, 2020, http://www.edu.gov.on.ca/eng/new/review-peel-district-school-board-report-en.pdf, 4-8.

122 Statistics Canada, July 25, 2018. https://www150.statcan.gc.ca/n1/daily-quotidien/181102/t001ceng.htm\#fn02; "Remains of 215 Children Found Buried at Former B.C. Residential School, First Nation Says," CBCnews (CBC/Radio Canada, May 29, 2021), https://www.cbc.ca/news/canada/britishcolumbia/tk-eml\%C3\%BAps-te-secw\%C3\%A9pemc-215-children-former-kamloops-indian-residentialschool-1.6043778.

${ }^{123}$ Milton Friedman, "The Role of Government in Education," 1955, 16-17.
} 
schools should be implemented, arguing that they would be a vehicle for promoting racial integration. Despising segregation and racial prejudice, Friedman believed that a voucher system, even one allowing schools to practice segregation, had the ability to facilitate the gradual transition towards increasingly mixed schools. ${ }^{124}$ However, he also argues that funds could be made available only to non-segregated schools, if necessary, though he did not mandate this regulation. ${ }^{125}$

He later argued that the "fundamental obstacle to the integration problem [was] maintaining the quality of schooling, [not] the racial problem." 126 To Friedman, vouchers allowed students from lower-income households the opportunity to attend expensive private schools, helping to bridge the gap between them and the wealthy. Since these racialized groups tend to be disproportionately poor, this system worked to break down both class and racial divisions. ${ }^{127}$

\section{Regulations Against Socio-Economic Inequalities}

In 2017, the OECD released "School Choice and School Vouchers: An OECD Perspective," a paper focused on reconciling some of the tensions within the school choice debate, based on their extensive research of voucher systems around the world. ${ }^{128}$ Recognizing the threat vouchers pose towards increasing socio-economic divides, the OECD recommended three key regulations be added to any voucher system: First, that the tuition accepted by voucher schools be heavily capped; 129 second, that schools can only be eligible for vouchers if they are incentivized to accept difficult students, potentially offering vouchers of higher value to the marginalized; ${ }^{130}$ and lastly, that governments should work to make information accessible to all. ${ }^{131}$ These regulations may be helpful in managing, and potentially reversing, both economic and social inequality.

124 Ibid., 16-17.

125 lbid., 16-17.

126 "Milton Friedman Speaks: Putting Learning Back in the Classroom (B1235)." YouTube video, September 10, 2021, https://youtu.be/JurdxfNQ0-Q, [33:33 - 35:00].

${ }^{127}$ Milton Friedman, "The Role of Government in Education," 1955, 6.

${ }^{128}$ For decades after its conception in the 1980s, Chile's voucher system allowed schools to select for students. As a result, socio-economic status was a significantly higher indicator of the learning outcomes of Chilean students than other OECD countries. Only after the 2016 Inclusion Law, the regulations that forbid the selection of students on economic, social, and academic grounds, began to grow teeth. Moreover, the bill also works towards ending "financiamiento compartido," the elimination of tuition fees and single-school subsidies. These recent laws are gradually being implemented, delaying the measurement of their effects. Andreas Schleicher, "School Choice and School Vouchers: An OECD Perspective," www.oecd.org, 2017, https://www.oecd.org/education/School-choice-and-schoolvouchers-an-OECD-perspective.pdf, 21-2.

129 lbid., 12-15.

130 Ibid., 14-16.

131 Ibid., 15. 


\section{Conclusion}

The school choice debate in Ontario is an issue that needs to be understood in the historical context of neoliberal reforms in Canadian education. Understanding the development of neoliberal models of education in Alberta and British Columbia gives us an insight into the potential trajectory of school choice policy in Ontario. Furthermore, the juxtaposition of Milton Friedman's ideas with the examples drawn from the history of education in Ontario sheds light on the complexities of the province's neoliberal reforms, namely the potential growth of socio-economic inequality fueled by school choice. The exploration of these issues lets us flag some of the shortcomings of school choice policy in Ontario, allowing us to pinpoint areas that need regulation.

\section{Acknowledgements}

I would like to thank my mentor Dr. Rosa Bruno-Jofre for her continuous guidance and encouragement. In addition, I am deeply grateful for Dave C. McNee, Patrick Bajorek, Kyungtae $\mathrm{Na}$, and Matt Montopoli for their painstaking assistance and scholarly support in the creation of this work. Lastly, I would also like to thank the blind reviewers and the editors of Encounters for their constructive feedback.

\section{References}

Alberta Education. "Bill 19 School Amendment Act 1994 (\$)." Accessed September 12, 2021. https://docs.assembly.ab.ca/LADDAR_files/docs/bills/bill/legislature_23/ session_2/19940210_bill-019.pdf.

Alberta Education. Charter Schoo/s Handbook. Https://Open.alberta.ca/Dataset. Edmonton, Alberta: Field Services, 2021. https://open.alberta.ca/dataset/77e47b84d8ff-4f2e-a77e-1db5c893595d/resource/c835df44-1cca-4252-8f60-2cf00bd66811 /download/edc-charter-schools-handbook-2021-02.pdf.

Alberta Education, "Survey Highlights. Open.alberta.ca/Dataset/. Choice in Education." 2020. https://open.alberta.ca/dataset/9dc29fa3-888f-4942-94ae-3348a544f62 a/resource/63205041-e109-44a4-b12c-ebf3eecabc4d/download/edc-surveyhighlights-choice-in-education-2020-05.pdf.

Allison, Derek J. "Bringing School Choice to Ontario." Fraser Institute, September 8, 2020. https://www.fraserinstitute.org/studies/bringing-school-choice-to-ontario.

Allison, Derek J. "Ontario Must Reform Education-for the Benefit of Parents and Students: Op-Ed." Fraser Institute, September 7, 2021. https://www. 
fraserinstitute.org/article/ontario-must-reform-education-for-the-benefit-of-parentsand-students.

Allison, Derek J., Sazid Hasan, and Deani Van Pelt. Rep. A Diverse Landscape: Independent Schoo/s in Canada, June 2016. https://www.fraserinstitute.org /sites/default/files/a-diverse-landscape-independent-schools-in-canada.pdf.

B.C. Ministry of Education Governance and Legislation Branch. "Independent School Act (1996)." Queen's Printer. Victoria, September 8, 2021. https://www.bclaws.gov.bc.ca/civix/document/id/complete/statreg/96216_01.

B.C. Legislature. "Independent Schools Support Act," 1977. https://www.bclaws.gov. bc.ca/civix/document/id/oic/arc_oic/1049_1977.

Baker, Rafferty. "What You Need to Know about Private Schools Getting Taxpayer Cash." CBC News, March 7, 2019. https://www.cbc.ca/news/canada/britishcolumbia/bc-private-school-funding-explainer-1.5043035.

Bakhov, Ivan Stepanovich. "Historical Dimension of the Formation of Multicultural Education in Canada." Pedagogika 117, no. 1 (2015): 7-15. https://doi.org/10.15823/p.2015.063.

Barrera, Jorge. "The Horrors of St. Anne's." CBC News, March 29, 2018. https:// newsinteractives.cbc.ca/longform/st-anne-residential-school-opp-documents.

Bascia, Nina; Sokolov Esther Fine, and Malcolm Levin. "Alternative Schooling and Student Engagement," 2017. https://doi.org/10.1007/978-3-319-54259-1.

BBC News. (2021, June 24). "Canada: 751 Unmarked Graves Found at Residential School." BBC. https://www.bbc.com/news/world-us-canada-57592243.

Berger, Ida. "The Influence of Religion on Philanthropy in Canada," 2021. https:// doi.org/10.32920/ryerson.14639034.v1.

Bethlenfalvy, Peter. "2021 Ontario Budget - Ontario's Action Plan: Protecting People's Health and Our Economy," 2021. https://budget.ontario.ca/2021/pdf/2021ontario-budget-en.pdf.

Bosetti, Lynn, and Dianne Gereluk. Understanding School Choice in Canada. Toronto, ON: University of Toronto Press, 2016.

Bound, John, and Sarah Turner. "Going to War and Going to College: Did World War II and the G.I. Bill Increase Educational Attainment for Returning Veterans?" Journal of Labor Economics 20, no. 4 (2002): 784-815. https://doi.org/10.3386/w7452.

Brown, Daniel J. "Financial Effects of Aid to Nonpublic Schools: The British Columbia Experience." Educational Evaluation and Policy Analysis 4, no. 4 (1982): 443-60. https://doi.org/10.3102/01623737004004443.

Caldas, Stephen J. and Sylvain Bernier. "The Effects of Competition from Private Schooling on French Public School Districts in the Province of Québec." The Journal of Educational Research 105, no. 5 (2012): 353-65. https://doi.org/10.1080/ 00220671.2011 .627400$.

Canadian Centre for Policy Alternatives. "About the Project." Accessed September 16, 2021. https://www.policyalternatives.ca/projects/education-project/about-us. 
Canadian Press. "Ontario's Education System Will Have a \$12.3-Billion Spending Gap by 2029-30: Watchdog." CBC News, May 31, 2021. https://www.cbc.ca/ news/canada/toronto/ontario-education-spending-gap-1.6047233.

Cardak, Buly A. "Education Vouchers, Growth and Income Inequality." SSRN Electronic Journal, 2003, 98-121. https://doi.org/10.2139/ssrn.378660.

Cardus. "David Hunt." September 14, 2021. https://www.cardus.ca/who-we-are/ourteam/david-hunt/.

CBC News. CBC Archives: Why Ontario Teachers Went on a Province-Wide Strike in 1997, Posted on February 21, 2020, https://www.cbc.ca/archives/why-ontarioteachers-went-on-a-province-wide-strike-in-1997-1.5466962.

CBC News. "Charter School Hopefuls Face Long Waiting Lists." September 5, 2013. https://www.cbc.ca/news/canada/calgary/charter-school-hopefuls-face-longwaiting-lists-1.1360685.

CBC News "Ontario Slightly Increases School Board Funding, but per Student Amount Drops Social Sharing," (Toronto, ON), April 26, 2019. https://www.cbc.ca/news/ canada/toronto/ontario-marginally-increases-school-board-funding-1.5112315.

Chandha, Ena, Suzanne Herbert, and Shawn Richard. Rep. Review of the Peel District School Board, February 28, 2020. http://www.edu.gov.on.ca/eng/new/review-peeldistrict-school-board-report-en.pdf.

Charter School Concept Paper. Government of Alberta, 2009. https://open.alberta.ca/ dataset/19acfdd7-f817-406b-a97d-aff203796be1/resource/0c8d2adc-d35f-4c018960-222c85bca05d/download/edc-charter-school-concept-paper.pdf.

Chidley-Hill, John. "Ryerson University to Change Name as Board Approves Task Force Recommendations." The National Post. August 26, 2021. https://nationalpost. com/news/canada/ryerson-universitys-board-of-governors-approvesrecommendation-to-change-name.

Clemens, Jason, Milagros Palacios, Jane Loyer, and Frazier Fathers. Measuring Choice and Competition in Canadian Education an Update on School Choice in Canada. Vancouver, BC: Fraser Institute, 2014.

Congress. "Document for June 22nd: Servicemen's Readjustment Act (GI Bill." National Archives and Records Administration. National Archives and Records Administration. Accessed November 22, 2021. https://www.archives.gov/historicaldocs/todays-doc/index.html?dod-date $=62$.

Crawley, Mike. "Ford Government's Claim of Spending '\$1.2B More' on Education Doesn't Add Up." CBC News, February 21, 2020. cbc.ca/news/canada/toronto/ ontario-teachers-strike-education-funding-increase-cuts-1.5462332.

Davies, Scott, and Janice Aurini. "Exploring School Choice in Canada: Who Chooses What and Why?" Canadian Public Policy 37, no. 4 (2011): 459-77. https://doi.org/ 10.3138/cpp.37.4.459. 
Dickson, Courtney, and Bridgette Watson. "Remains of 215 Children Found Buried at Former B.C. Residential School, First Nation Says." CBC News, March 27, 2021. https://www.cbc.ca/news/canada/british-columbia/tk-eml\%C3\%BAps-tesecw\%C3\%A9pemc-215-children-former-kamloops-indian-residential-school1.6043778.

Eaton, Armelia. "From Grade Inflation to Grade Deflation." The Varsity, September 23, 2018. https://thevarsity.ca/2018/09/23/from-grade-inflation-to-grade-deflation/.

The Economist. "Suck It and See; Education in Canada; School Vouchers in Ontario." 359, no. 8228 (June 30, 2001).

Education Alberta. "Choice in Education Engagement." June 24, 2020. https://www.alberta.ca/choice-in-education-engagement.aspx.

Ferguson, Rob. "Doug Ford Wins Riding as Progressive Conservatives Sweep to Power." Toronto Star, June 7, 2018. https://www.thestar.com/news/queenspark/ 2018/06/07/doug-ford-wins-riding-as-progressive-conservatives-sweep-topower.html.

Financial Accountability Office of Ontario. Rep. Ministry of Education: Spending Plan Review, May 31, 2021. https://www.fao-on.org/web/default/files/publications/ FA2102\%20Education\%20Estimates/Education\%20Spending\%20Plan\%20ReviewEN.pdf.

Find a School Tool - Edmonton Public Schools. "Find a School (2021-22)." Accessed September 16, 2021. https://www.epsb.ca/schools/findaschool/fast/.

Free To Choose Network. "Milton Friedman Speaks: Putting Learning Back in the Classroom (B1235)." YouTube video, September 10, 2021, https://youtu.be/ JurdxfNQ0-Q.

Freeze, Colin, and Karen Howlett. "McGuinty Government Rules out Use of Sharia Law." The Globe and Mail, September 12, 2005. https://www.theglobeandmail.com/news/national/mcguinty-government-rules-outuse-of-sharia-law/article18247682/.

French, Janet. "First New Charter School in 13 Years Could Open in Alberta." CBC, October 4, 2020. https://www.cbc.ca/news/canada/calgary/charter-school-capremoval-criticized-1.5164989.

Friedman, Milton. 1955. The role of government in education. New Brunswick, N.J.: Rutgers University Press.

Gillespie, Kerry. "John Tory Puts Faith in School Religion." Toronto Star, July 24, 2007. https://www.thestar.com/news/ontario/2007/07/24/john_tory_puts_faith_in_school_r eligion.html.

Government of Alberta. "Bill 15 Choice in Education Act," 2020. https://docs.assembly. ab.ca/LADDAR_files/docs/bills/bill/legislature_30/session_2/20200225_bill-015.pdf .

Government of Alberta. Funding Manual For School Authorities 2012/2013. Edmonton, Alberta: Alberta Education School Finance Branch, 2012. https://open.alberta.ca/ dataset/8f3b4972-4c47-4009-a090-5b470e68d633/resource/fb440809-92b8-434f- 
a9a0-d3927969f8b0/download/2063184-2012-2013-funding-manual-for-schoolauthorities-final.pdf.

Government of Alberta. "Protecting Choice in Education | Protéger Le Choix Des Albertains Et Albertaines En Matière D'éducation." May 28, 2020. https://www.alberta.ca/release.cfm?xID=71459A1642543-0985-9A93C18D61E2A25252C5.

Government of Ontario. "Learn About OSAP." Ontario.ca. Accessed September 14, 2021. https://www.ontario.

ca/page/learn-about-osap.

Government of Ontario. "Ontario Child Care Tax Credit." ontario.ca. Accessed

November 14, 2021. https://www.ontario.ca/page/ontario-child-care-tax-credit.

Green, Erica L. "DeVos Funnels Coronavirus Relief Funds to Favored Private and Religious Schools." The New York Times, May 15, 2020. https://www.nytimes.com/ 2020/05/15/us/politics/betsy-devos-coronavirus-religious-schools.html.

Guillemette, Yvan. "Breaking Down Monopolies: Expanding Choice and Competition in Education." C.D. Howe Institute, 2007. https://ofis.ca/wp-content/uploads/2012/ 08/CD-Howe-Institute-Breaking_Down_Monopolies-October-2007.pdf.

Hart, Doug, and Arlo Kempf. Rep. Public Attitudes Towards Education in Ontario 2018 20th. Vol. 20th. OISE Survey of Educational Issues. Toronto, ON: Ontario Institute for Studies in Education of the University of Toronto, 2018. https://www.oise.utoronto. $\mathrm{ca} /$ oise/UserFiles/Media/Media_Relations/OISE-Public-Attitudes-Report2018_final.pdf.

Harvey, David. A Brief History of Neoliberalism. Johanneshov: MTM, 2019.

Hill, Phillip G. "Public Education and Moral Monsters: A Conversation with Noam Chomsky." Our Schools/Our Selves: Winter 2001, January 1, 2001.

https://www.policyalternatives.ca/publications/ourschools-ourselves/010101. Hunt, David and Deani Van Pelt, Who Chooses Independent Schools in British Columbia and Why? (Ottawa: Cardus, 2019), 12, accessed September 30, 2021, https://www.cardus.ca/research/education/reports/who-chooses-independentschools-in-british-columbia-and-why/education/reports/who-chooses-independentschools-in-british-columbia-and-why/.

ILEA Ontario. "About ILP.” November 15, 2015. https://ilea.ca/news-2/ilp/.

International Baccalaureate Schools of Ontario. "IB Programme in Ontario Schools." World School, 2008. https://www.tcdsb.org/schools/michaelpowerstjoseph/ ib/Resources/Documents/IBSO_Brochure.pdf.

Jason, Clemens. Rep. Wait Lists for Independent Schools in British Columbia's Lower

Mainland, October 2012. https://www.fraserinstitute.org/sites/default/files/wait-listsfor-independent-schools-in-BCs-lower-mainland.pdf. Joannou, Ashley. "Parents in Alberta Already Have Significant Choice': Teachers' Association Says Bill 15 Would Do Little to Help Most Students." Edmonton Journal, May 29, 2020. https://edmontonjournal.com/news/local-news/parents-in-alberta- 
already-have-significant-choice-teachers-association-says-bill-15-would-do-little-tohelp-most-students.

Johnson, David. Identifying Alberta's Best Schools. C. D. Howie Institute. Toronto, Ont.: C.D. Howe Institute, 2013. https://www.cdhowe.org/sites/default/files/ attachments/research_papers/mixed/e-brief_164_0.pdf.

Karen, Howlett. "Tory Admits Faith-Based Schools Funding Mistake." The Globe and Mail, October 25, 2007. https://www.theglobeandmail.com/news/national/toryadmits-faith-based-schools-funding-mistake/article18147998/.

Kunin, Jason. "Pandemic Has Cleared the Way for Doug Ford's Plans to Privatize Education." Rabble, September 22, 2020. https://rabble.ca/news/2020/09/ pandemic-has-cleared-way-doug-fords-plans-privatize-education.

Lau, Matthew. "After Doug Ford, Maybe Ontario's Liberals Will Finally Embrace School Choice." Financial Post, February 6, 2019. https://financialpost.com/opinion/ matthew-lau-after-doug-ford-maybe-ontarios-liberals-will-finally-embrace-schoolchoice.

Lau, Matthew. "Let's Have Diversity of School Choices." The Financial Post. June 16, 2020. https://financialpost.com/opinion/lets-have-diversity-of-school-choices.

Legislative Assembly of Alberta. "Bill 15 Choice in Education Act, 2020." docs.assembly.ab.ca, 2020. https://docs.assembly.ab.ca/LADDAR_files/docs/ bills/bill/legislature_30/session_2/20200225_bill-015.pdf.

Lewis, Michael. "Teachers, Students Rally at Queen's Park to Protest Proposed Education Cuts." Toronto Star, April 6" ${ }^{\text {th }}$ 2019, Accessed September 14, 2021. https://www.thestar.com/news/gta/2019/04/06/unions-to-hold-rally-at-ontariolegislature-to-protest-education-cuts.html.

Lysyk, Bonnie. Rep. 2013 Annual Report. Queen's Printer for Ontario, 2013. https:// www.auditor.on.ca/en/content/annualreports/arreports/en13/2013ar_en_web.pdf.

Martin Family Initiative. "66 Archives." Promising Practices in Indigenous Education Website, May 2015. https://ppw.themfi.ca/en/ppwissues/66.

Mindzak, Michael. "What Happened to Charter Schools in Canada?" Equity \& Excellence in Education 48, no. 1 (2015): 105-17. https://doi.org/10.1080/10665684. 2015.991162.

Novogrodsky, Myra. "Looking Backward and Forward: Fifty Years of Alternative Schools." Alternative Schooling and Student Engagement, 2017, 95-106. https:// doi.org/10.1007/978-3-319-54259-1_7.

Ontario Ministry of Education. "Ontario Schools Kindergarten to Grade 12: Policy and Program Requirements," 2016. http://www.edu.gov.on.ca/eng/document/policy/os/ onschools_2016e.pdf.

Ontario Ministry of Education. "Private Elementary and Secondary Schools." Government of Ontario, April 1, 2021. http://www.edu.gov.on.ca/eng/general/ elemsec/privsch/. 
Ontario Ministry of Education. "Quick Facts: Ontario Schools, 2016-17," 2019. http://www.edu.gov.on.ca/eng/general/elemsec/quickfacts/2016_2017.html. Ontario Ministry of Finance. "Equity In Education Tax Credit Discussion Paper." Toronto, August 30, 2001. https://www.fin.gov.on.ca/en/publications/2001/ edeqe.pdf.

Ontario Secondary School Teachers' Federation; Update: Toronto." Toronto, November 21, 2000. https://proxy.queensu.ca/login?qurl=https\%3A\%2F\%2Fwww. proquest.com\%2Ftrade-journals\%2Falliance-party-favours-voucher-education \%2Fdocview\%2F220873208\%2Fse-2\%3Faccountid\%3D6180.

OSSTF/FEESO. "A Report Made to Order." Update, October 25, 2018. https:// osstfupdate.ca/2018/10/25/a-report-made-to-order/.

Ourkids.net. Overview of provincial funding for private school in Canada. Accessed September 13, 2021. https://www.ourkids.net/school/provincial-funding-for-privateschools.

Paikin, Steve. "Public Funding of Catholic Schools in Ontario," July 4, 1985. https://www.cbc.ca/archives/entry/public-funding-of-catholic-schools-in-ontario.

Palacios, Milagros, and Mark Milke. "Ontario Parents Deserve More School Choices for Their Children: Op-Ed." Fraser Institute, December 23, 2015. https://www. fraserinstitute.org/article/ontario-parents-deserve-more-school-choices-theirchildren.

Press Progress. "Doug Ford's 2021 Budget Confirms Over $\$ 1$ Billion in Cuts to Education, Ontario School Boards Say." March 24, 2021. https://pressprogress.ca/ doug-fords-2021-budget-confirms-over-1-billion-in-cuts-to-education-ontarioschool-boards-say/.

Province of British Columbia. "Framework for Enhancing Student Learning." Hansard Services, January 13, 2021. https://www2.gov.bc.ca/gov/content/educationtraining/k-12/administration/legislation-policy/public-schools/framework.

Sandström, F. Mikael, and Fredrik Bergström. "School Vouchers in Practice: Competition Will Not Hurt You." Journal of Public Economics 89, no. 2-3 (2005): 351-80. https://doi.org/10.1016/j.jpubeco.2004.03.004.

Schleicher, Andreas. "School Choice and School Vouchers: An OECD Perspective." www.oecd.org, 2017. https://www.oecd.org/education/School-choice-and-schoolvouchers-an-OECD-perspective.pdf.

School Vouchers Anyone? YouTube, 2018. https://www.youtube.com/watch?v=a8

TZIhpIV6c\&feature=youtu.be\&ab_channel=TheAgendawithStevePaikin.

Schools Act (Government of British Columbia). Accessed September 6, 2021. https://www.bclaws.gov.bc.ca/civix/document/id/complete/statreg/96412_02\#sectio n2.

Shaker, Erika. "Frontlines of the Class." The Monitor, March 1, 2019. https://www. policyalternatives.ca/publications/monitor/frontlines-class. 
Shapiro, Bernard J. Rep. The Report of The Commission on Private Schools in Ontario. Toronto, ON: Ministry of Education, 1985. https://archive.org/details/reportof privschools00comm.

Sharp, Morgan. "Scarcity Is the Point, Says Critic of Ford's Back-to-School Fail." Canada's National Observer, October 15, 2020. https://www.nationalobserver.com/ 2020/10/15/news/scarcity-point-says-critic-fords-back-school-fail.

Shea, Tom. "The Problem with Voucher Education." The Hamilton Spectator, February 29, 2020. https://www.thespec.com/opinion/columnists/2013/01/28/the-problemwith-voucher-education.html.

Statistics Canada. "Table 1 Number and Proportion of Students in Elementary and Secondary Schools, by School Type, Canada, Provinces and Territories, 2016/2017," February 11, 2018. https://www150.statcan.gc.ca/n1/dailyquotidien/181102/t001c-eng.htm\#fn02.

Statistics Canada. "The Educational Attainment of Aboriginal Peoples in Canada," July 25, 2018. https://www12.statcan.gc.ca/nhs-enm/2011/as-sa/99-012-x/99-012x2011003_3-eng.cfm.

Teachers, Toronto. "Cuts and Vouchers and Funding for Non-School Board Delivered Online LEARNING. Elect Them Again and It'Il Be Charters and PRIVATIZATION next. @FORDNATION'S 2021 Budget Confirms over \$1 Billion in Cuts to Education, Ontario School Boards SAY \#ONTED \#Onpoli Https://T.co/UM1tPfW9px." Twitter. Twitter, March 26, 2021. https://twitter.com/osstftoronto/status/137527697483 1235080.

Thames Valley District School Board, "School within a School." Accessed September 14, 2021. https://www.tvdsb.ca/en/programs/school-within-a-school.aspx. The Agenda with Steve Paikin, "School Vouchers Anyone?" YouTube. YouTube, 2018. https://www.youtube.com/watch?v=a8TZIhpIV6c\&ab_channel=TheAgendawithSteve Paikin.

The Review. "Ontario Boosts per Pupil Funding Amount by Two per Cent, Spending $\$ 736$ Million More in Public Education." June 19, 2020. https://thereview.ca/2020/ 06/19/ontario-boosts-per-pupil-funding-amount-by-two-per-cent-spending-736million-more-in-public-education/.

Toronto District School Board. "Africentric Alternative SCHOOL (GR. JK-08)." Accessed September 14, 2021. https://www.tdsb.on.ca/Find-your/Schools/ schno/3949.

Toronto District School Board. "Da Vinci SCHOOL (GR. JK-06)." Accessed September 14, 2021. https://www.tdsb.on.ca/Find-your/Schools/schno/5905.

Toronto District School Board. "Kapapamahchakwew - Wandering Spirit School." 2014. https://www.tdsb.on.ca/Community/Indigenous-Education/Schools/ Kapapamahchakwew-Wandering-Spirit-School.

The Protestant Separate School Board (2021). "Welcome to Protestant Separate

School Board of the Town of Penetanguishene." https://www.pssbp.ca/. 